\title{
Impact of AMO enhancing human resource management practices on sustainable competitive advantage in insurance companies in Qatar
}

\author{
Tamadur Mesfer Al-shahwani ${ }^{\mathbf{a}^{*}}$
}

${ }^{a}$ Senior Administrative Researcher Grade Section, Financial Institution Supervision Sector, Qatar Central Bank, Qatar

\begin{tabular}{l}
\hline C H R O N I C L E \\
\hline Article history: \\
Received: October 9, 2019 \\
Received in revised format: No- \\
vember 252019 \\
Accepted: December 27, 2019 \\
Available online: \\
December 27, 2019 \\
\hline Keywords: \\
AMO Model \\
Human Resource Management \\
Practices \\
Sustainable Competitive Ad- \\
vantage \\
Insurance Companies \\
Qatar
\end{tabular}

\section{A B S T R A C T}

\begin{abstract}
This research aims to explore the impact of ability, motivation, and opportunity (AMO) model to enhance human resource management practices on sustainable competitive advantage. The dimensions of the AMO model were ability-enhancing human resource management practices, motivation-enhancing human resource management practices, and opportunity-enhancing human resource management practices. The population consisted of all managers on the top managerial level at insurance companies. The purposive sample was composed of (124) managers, where the questionnaires returned, and valid for statistical analysis were (106), with the responding rate $(85.5 \%)$. Structural equation modeling was used for statistical analysis and testing research's hypotheses. The results indicated that all dimensions of AMO model to enhance human resource management practices had influenced on sustainable competitive advantage. Hence, the recommendations were oriented to the organizations to improve the recruitment and training practices, as well as encouraging the employees by fair compensations and empowering them to achieve the organization's goals.
\end{abstract}

(C) 2020 by the authors; licensee Growing Science, Canada

\section{Introduction}

Organizations continually focused on determining their long-term strategic goals which enable them of survival in an uncertain environment (Morton et al., 2018). The sustainable competitive advantage deemed an important purpose to ensure the organization coping with hyper-competition and attain the forefront of their industrial sector despite the global challenges (Čirjevskis, 2019). Therefore, the management sought to enhance their competitive performance in order to achieve a sustainable competitive through focusing on the internal environment and the external environment (Al-Abdallah et al., 2014). The internal environment focus is represented by emphasizing on the importance of production factors that the organization acquired (Xin et al., 2018). Human resource considered the most critical factor among production factors through associating with the innovating process that contributing to building a competitive advantage (Wang, 2019). Hence, the current management theories is to focus on how to activate the role of the human resource of achieving the organization goals (Mahdi et al., 2019a). One of the newest theories is the framework of ability, motivation, and opportunity which emphasize on enhancing human resource management practices to attain a high performance (Ma et al., 2017). The insurance sector is considered as one of the major sectors which shapes the Qatar economy, especially after Qatar orientation toward keeping up the last global developments. This orientation came in line with Qatar's vision for the future years, which focuses on Qatar's global position by providing the best services, adopting entrepreneurial thoughts and innovative work, which is reflected on insurance companies' works. Accordingly, this research is seeking to examine the impact of ability, motivation, and opportunity (AMO) enhancing human resource management practices on sustainable competitive advantage in insurance companies at Qatar. 


\section{Literature review and hypotheses development}

\subsection{AMO Human Resource Practices}

Counter of the conventional view about human resource management depicted as secluded, researches in the last years has switched their efforts toward deeming human resource management practices as an open system that consists of interrelated functions (Kundu \& Gahlawat, 2018). One of these systems emerged called high-performance work system (HPWS) to describe how human resource management practices indirectly affect employees behaviors and attitudes in order to attain high job performance depending on the increase of employees abilities, motivate them, and provide opportunities for them to share on achieving organization's goals (Li et al., 2019; Zhang \& Morris, 2014). The AMO model acts the strategic importance of HPWS in a precise method by focusing mainly on human resource management practices that enhancing discretionary behavior between staff (Appelbaum, 2000). Furthermore, the root of this model depends on psychology concepts that are linked to the systems which determine individual characteristics (Kroon et al., 2013; Rajiani et al., 2016), where they are emphasized on employees own the suitable abilities, working on motivating staff to boost discretionary behavior, and empowering staff toward organizational goals (Harney \& Jordan, 2008). Marin-Garcia and Tomas (2016) argued that the AMO model that enhances human resource management practices interrelating with attaining strategic goals of an organization is an extremely complicated issue. Whereas this model is based not only on an actual of a group of practices but also it depends on employee personal comprehensions of these practices (Ehrnrooth \& Björkman, 2012). Thus, we should differentiate between actual and expected human resource management practices (Vermeeren et al., 2014). Some authors debated that adopting the AMO model as a perspective focusing on employees is more effective than the administrative perspective to explain the mechanisms of changing in employees behaviors (Bos-Nehles et al., 2013). Hence, this view described that the perfect design of human resource practices not only ensures an effective executive, but it emphasizes on the managers' capabilities to execute these practices, encourage to implement the jobs, and the organizational aid to make the change needed (Bainbridge, 2015; MarinGarcia \& Tomas, 2016). Indeed, this model considers a three-dimensional model consisting of ability, motivation, and opportunity to enhance human resource management practices (Kundu \& Gahlawat, 2018; Pak et al., 2019; Rajiani et al., 2016). "Ability" focuses on improving the employees' capabilities and skills by a set of functions that are aimed to recruit talented candidates, conducting extensive programs for training and developing, and working on job enrichment (Bainbridge, 2015; Pak et al., 2019). "Motivation" refers to encourage employees to perform their jobs optimally through rewards and incentives, job security, and career development (Kundu \& Gahlawat, 2018). "Opportunity" demonstrates the open horizons for staff to participate in the organization's success by information involvement, work as a team, and to empower their employees (Obeidat et al., 2016; Rajiani et al., 2016).

\subsection{Sustainable Competitive Advantage}

Competitive advantage could be created either by executing a value generation strategy that exists or potential rivals (Gouillart, 2014) or by the superior implementation of strategies which rivals adopt (Santana-Sarmiento et al., 2019). Jabir et al. (2019) identified the competitive advantage as the unique status of the organization that enables it to cope rivals, while Khan et al. (2019) indicated that competitive advantage fundamentally derived from the organization's resources and capabilities. The resources have been referred to the assets an organization acquired that deem as a stash of obtainable factors and one of an organization's strengths and weaknesses (Bowman \& Ambrosini, 2003; Holdford, 2018). The capabilities are considered as the organization ability to integrate its resources together for developing its products by managing brand which is based on the organization knowledge about its market needs (Holdford, 2018; Maja et al., 2018; Takahashi \& Sander, 2017). The term sustainable competitive advantage has received immense importance since Porter (1980) drawn the broad lines of how organizations developed their strategies to interact with their markets through the generic competitive strategies classified into cost leadership, differentiation, or focus (Quaye \& Mensah, 2019). Barney (2000) stated that sustainable competitive advantage expresses those unique value generation activities in the long term and asynchronous with prospective rivals where these activities cannot be readily imitated (Nadarajah \& Latifah Syed Abdul Kadir, 2014). Hence, the extent of contribution an organization could obtain from a competitive advantage depends on the sustainability of this competitive advantage that the resources and capabilities confer on an organization (Maury, 2018). Moreover, Mahdi et al., (2019) argued that the sustainability of competitive advantage could be achieved when the organization competitive advantage withstands for the erosion that results by the competitive behavior through building barriers which prevent the imitation.

\subsection{AMO Human Resource Practices and sustainable competitive advantage}

The AMO framework constitutes the most common theoretical notion associated with human resource management systems, especially it reflects the effects of their practices on an organization's outcomes (Jiang et al., 2012). This framework suggests three major components enhancing human resource management practices to achieve an organization's goals (Kundu \& Gahlawat, 2018). Hence, this enhancing practices could improve an organization ability to build sustainable competitive advantage (Bułat, 2019). Ability enhances human resource management practices by recruiting talent which deems the base of innovative organizations (Pak et al., 2019), selecting the best available talent for fusing among organization's teams (Rajiani et al., 2016), and providing training to help them develop their skills and capabilities (Obeidat et al., 2016) leading to increase an organization's opportunities to attain sustainable competitive advantage by improving its ability to utilize its resources and capabilities to provide unique products and services to their customers (Albrecht et al., 2015). Therefore, the first hypothesis indicates: 
$\mathrm{H}_{1}$ : There is a significant impact of ability enhancing HRM practices on sustainable competitive advantage.

Motivation is enhancing human resource management practices through focusing an organization on granting their employees fair compensation either monetary or non-monetary as the result of high performance (Marin-Garcia \& Tomas, 2016), career management of their employees that is based on an equal opportunity (Almutawa et al., 2016), and providing an organizational environment characterized on job security (Li et al., 2019) driving their employees to keep an organization's resources and seeking to develop its market share through creating novel products and services that increase an organization's ability to compete (Bos-Nehles et al., 2013), as well as enhance on their loyalty to attain an organization's competitive position (Bułat, 2019). Accordingly, the second hypothesis refers to:

$\mathrm{H}_{2}$ : There is a significant impact of motivation enhancing HRM practices on sustainable competitive advantage.

Opportunity enhancing human resource management practices is based on enabling the employees to share on planning the future of an organization through engaging them on the decision-making process (Marin-Garcia \& Tomas, 2016), opening the communication channels between different levels within an organization (Ma et al., 2017), building teamwork spirit (Rajiani et al., 2016) and these factors help organizations build a strong competitive advantage through employees commitment for organization's goals accomplishment in efficient and effective methods (Albrecht et al., 2015). Therefore, the third hypothesis states:

$\mathrm{H}_{3}$ : There is a significant impact of opportunity enhancing HRM practices on sustainable competitive advantage.

\section{Research theoretical model}

Fig. 1 provides an overall view of the hypothesized impact of the independent variable that is referred to AMO enhancing human resource management practices through their dimensions on the dependent variable that identified as a sustainable competitive advantage.

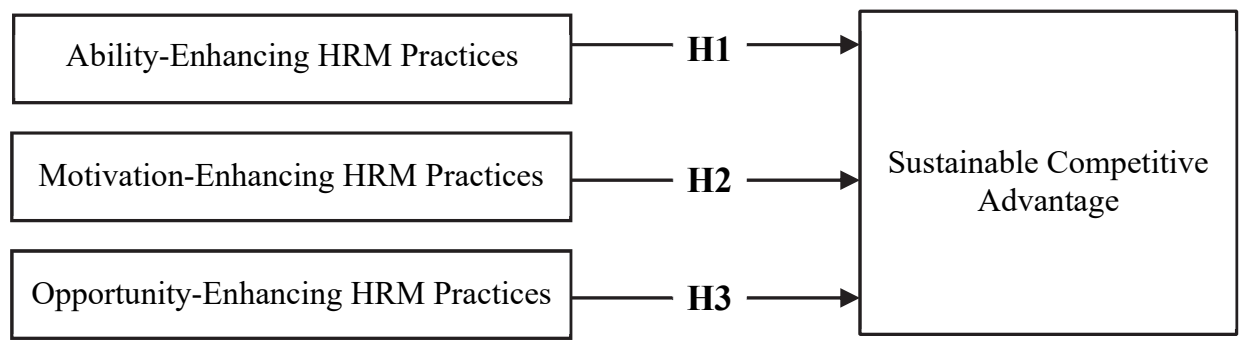

\section{Methodology}

Fig. 1. Theoretical Model

\subsection{Research population and sample}

The research population consisted of the managers in the top management level at insurance companies in Qatar. The research was conducted with this population due to the importance of this sector in the Qatar economy. The research sample was purposive (Klar \& Leeper, 2019), where the questionnaires were distributed to (124) managers, while the returned questionnaires and valid for statistical analysis were (106) with responding rate $(85.5 \%)$. Table 1 shows the characteristics of the research sample.

Table 1

Sample Characteristics

\begin{tabular}{|c|c|c|c|}
\hline Variables & Categories & Frequency & Percentage \\
\hline \multirow{2}{*}{ Gender } & Male & 87 & $82.1 \%$ \\
\hline & Female & 19 & $17.9 \%$ \\
\hline \multirow{4}{*}{ Age Group } & Less than 30 & 12 & $11.3 \%$ \\
\hline & From 30 To less than 40 & 34 & $32.0 \%$ \\
\hline & From 40 To less than 50 & 52 & $49.0 \%$ \\
\hline & More than 50 & 8 & $7.7 \%$ \\
\hline \multirow{4}{*}{ Qualification } & Diploma and less & 3 & $2.8 \%$ \\
\hline & Bachelor & 60 & $56.6 \%$ \\
\hline & Master & 28 & $26.4 \%$ \\
\hline & Doctorate & 15 & $14.2 \%$ \\
\hline
\end{tabular}

\subsection{Research instrument}

The data was collected from the research sample using a questionnaire that deemed the main research instrument. It was developed by reviewing the literature related to research variables and consisted of 42 items used to measure these variables. Table 2 describes the distribution of items on the research's variables and dimensions. 
Table 2

Variables Items

\begin{tabular}{|c|c|c|c|}
\hline Variables & Dimensions & No. Items & Reference \\
\hline \multirow{3}{*}{ AMO Enhancing HRM Practices } & Ability-Enhancing HRMPs & 10 & \multirow{3}{*}{$\begin{array}{l}\text { (Kundu \& Tomas, 2016; Obeidat et al., } \\
\text { 2016) }\end{array}$} \\
\hline & Motivation-Enhancing HRMPs & 12 & \\
\hline & Opportunity-Enhancing HRMPs & 12 & \\
\hline Sustainable Competitive Advantage & & 8 & $\begin{array}{l}\text { (Holdford, 2018; Khan et al., 2019; } \\
\text { Maury, 2018; Quaye \& Mensah, 2019) }\end{array}$ \\
\hline
\end{tabular}

\subsection{Validity and Reliability}

Exploratory factor analysis was used as a method to identify how items are loaded on the specific structures (Hancock et al., 2019). This method is used to achieve several objectives such as decreasing the number of structures used in the research model, evaluating the dimensionality of structures, examining multicollinearity besides describing relationships between variables (Williams et al., 2010). Moreover, Ab Hamid et al. (2017) and Al-Hawary and Al-Namlan (2018) referred that exploratory factor analysis is used to ensure validity and reliability of the research instrument, where it measures the convergent validity by average variance extracted (AVE), discriminant validity using the square root of the average variance extracted ( $\sqrt{A V E})$, and reliability through calculating McDonald's omega coefficient $(\omega)$.

Table 3

Exploratory Factor Analysis Results

\begin{tabular}{|c|c|c|c|c|c|}
\hline Variables & Items & $\lambda$ & AVE & $\omega$ & $\sqrt{A V E}$ \\
\hline \multirow{10}{*}{ Ability-Enhancing HRM Practices } & AEP1 & 0.871 & \multirow{10}{*}{0.613} & \multirow{10}{*}{0.940} & \multirow{10}{*}{0.782} \\
\hline & AEP2 & 0.753 & & & \\
\hline & AEP3 & 0.778 & & & \\
\hline & AEP4 & 0.786 & & & \\
\hline & AEP5 & 0.843 & & & \\
\hline & AEP6 & 0.792 & & & \\
\hline & AEP7 & 0.711 & & & \\
\hline & AEP8 & 0.668 & & & \\
\hline & AEP9 & 0.785 & & & \\
\hline & AEP10 & 0.819 & & & \\
\hline \multirow{12}{*}{ Motivation-Enhancing HRM Practices } & MEP1 & 0.792 & \multirow{12}{*}{0.540} & \multirow{12}{*}{0.933} & \multirow{12}{*}{0.734} \\
\hline & MEP2 & 0.734 & & & \\
\hline & MEP3 & 0.785 & & & \\
\hline & MEP4 & 0.813 & & & \\
\hline & MEP5 & 0.647 & & & \\
\hline & MEP6 & 0.684 & & & \\
\hline & MEP7 & 0.697 & & & \\
\hline & MEP8 & 0.653 & & & \\
\hline & MEP9 & 0.733 & & & \\
\hline & MEP10 & 0.761 & & & \\
\hline & MEP11 & 0.780 & & & \\
\hline & MEP12 & 0.716 & & & \\
\hline \multirow{12}{*}{ Opportunity-Enhancing HRM Practices } & OEP1 & 0.748 & \multirow{12}{*}{0.548} & \multirow{12}{*}{0.935} & \multirow{12}{*}{0.740} \\
\hline & OEP2 & 0.637 & & & \\
\hline & OEP3 & 0.751 & & & \\
\hline & OEP4 & 0.738 & & & \\
\hline & OEP5 & 0.764 & & & \\
\hline & OEP6 & 0.729 & & & \\
\hline & OEP7 & 0.628 & & & \\
\hline & OEP8 & 0.834 & & & \\
\hline & OEP9 & 0.871 & & & \\
\hline & OEP10 & 0.617 & & & \\
\hline & OEP11 & 0.736 & & & \\
\hline & OEP12 & 0.788 & & & \\
\hline \multirow{8}{*}{ Sustainable Competitive Advantage } & SCA1 & 0.781 & \multirow{8}{*}{0.563} & \multirow{8}{*}{0.911} & \multirow{8}{*}{0.750} \\
\hline & SCA2 & 0.765 & & & \\
\hline & SCA3 & 0.801 & & & \\
\hline & SCA4 & 0.764 & & & \\
\hline & SCA5 & 0.625 & & & \\
\hline & SCA6 & 0.755 & & & \\
\hline & SCA7 & 0.738 & & & \\
\hline & SCA8 & 0.761 & & & \\
\hline
\end{tabular}

Kaiser-Mever-Olkin (KMO) measure of sampling adequacy $=0.821$

The results listed in Table 3 indicate that all items loading values $(\lambda)$ were higher than 0.50 , where the values were between 0.625 and 0.871 ; hence all items are accepted (Al-Hawary \& Al-Namlan, 2018). The average variance extracted (AVE) is higher than 0.50, which means that the convergent validity was accepted (Al-Hawary et al., 2018; Rahman et al., 2016). The square root of the average variance extracted $(\sqrt{ } \mathrm{AVE})$ is associated with values higher than the bivariate correlation coefficients, where the discriminate validity is considered acceptable (Ab Hamid et al., 2017). Moreover, McDonald's omega coefficient came between 0.911 and 0.940 , which indicates that all omega values are higher than the threshold criterion, i.e. 0.70 (Meneses et al., 2019; Saldivia et al., 2019). Hence, the research instrument is characterized by validity and reliability. 


\subsection{Goodness of Model Indices}

In terms of model fit indices, confirmatory factor analysis (CFA) was used to confirm the results that appeared in exploratory factor analysis (EFA) (Howard et al., 2018). Therefore, Enders and Mansolf (2018) determined six indices used to signify whether the model used is fit or not, these indices were relative chi-square ( $\chi 2 / \mathrm{DF})$, the goodness of fit index (GFI), the comparative fit index (CFI), adjusted goodness of fit index (AGFI), the Tucker-Lewis index (TLI), and root mean square error of approximation (RMSEA).

Table 4

Confirmatory Factor Analysis Results

\begin{tabular}{lccc}
\hline Index & Value & Criterion & Results \\
\hline$\chi 2 / D F$ & 1.89 & $<3$ & \\
GFI & 0.931 & $>0.90$ & \\
CFI & 0.944 & $>0.90$ & Supported \\
AGFI & 0.925 & $>0.90$ & Supported \\
TLI & 0.937 & $>0.90$ & Supported \\
RMSEA & 0.024 & $<0.05$ & Supported \\
\hline
\end{tabular}

The results in the Table 4 confirm that the model used is fit, where relative chi-square $(\chi 2 / \mathrm{DF})$ value was less than 3 (AlHawary \& Mohammed, 2017), all vales of the goodness of fit index (GFI), comparative fit index (CFI), adjusted goodness of fit index (AGFI), the Tucker-Lewis index (TLI) were higher than 0.90 (Marsh et al., 2019), and root mean square error of approximation (RMSEA) value was less than 0.05 (Perry et al., 2015).

\section{Data analysis}

The Pearson correlation coefficient identifies the correlation between research variables, as well as it enables to confirm that the variables are free of multicollinearity problem (Wang et al., 2018).

Table 5

Means, Standard Deviation and Correlation Coefficients

\begin{tabular}{clcccc}
\hline Variables & Ability-Enhancing HRM Practices & Mean & SDs & $\mathbf{1}$ & $\mathbf{2}$ \\
\hline 1. & Motivation-Enhancing HRM Practices & 3.74 & 0.91 & - & $\mathbf{3}$ \\
2. & Opportunity-Enhancing HRM Practices & 3.54 & 0.93 & $0.45^{*}$ & - \\
3. & Sustainable Competitive Advantage & 3.08 & 0.89 & $0.63^{*}$ & $0.41^{*}$ \\
\hline
\end{tabular}

Notes: ** Correlation is significant at $(\alpha \leq 0.01) . *$ Correlation is significant at $(\alpha \leq 0.05)$.

The results as shown in Table 5 indicate that there is a correlation between variables, where the values range from $\mathrm{r}=0.31$ to $\mathrm{r}=0.63$ with significance level less than 0.05 (Jiang, 2018). Furthermore, all correlation values are less than 0.80 which means that independent variables are free of multicollinearity problem (Hair, 2010). Moreover, the results in Table 5 refers that the insurance companies in Qatar were implementing human resource management practices that relate to ability-enhancing with high level $(\mathrm{M}=3.74, \mathrm{SD}=0.91)$. While they implement human resource management practices that relate to motivation-enhancing with a moderate level $(\mathrm{M}=3.54, \mathrm{SD}=0.93)$ and opportunity-enhancing was also a moderate level $(\mathrm{M}=3.08, \mathrm{SD}=0.89)$. Also, the sustainable competitive advantage achievement was at a moderate level $(\mathrm{M}=3.17, \mathrm{SD}=0.94)$. Structural equation modeling was used to test the research hypotheses, where it explains the impact between Ability-Enhancing HRM Practices and sustainable competitive advantage (H1), Motivation-Enhancing HRM Practices and sustainable competitive advantage (H2), and Opportunity-Enhancing HRM Practices and sustainable competitive advantage (H3) as shown in Fig. 2. Accordingly, the results of structural equation modeling which was used to test research hypotheses are explained in Table 6.

Table 6

Hypothesis Test

\begin{tabular}{llc}
\hline Independent variables & $\beta$ & C.R. \\
\hline Ability-Enhancing HRM Practices & 0.51 & 4.26 \\
Motivation-Enhancing HRM Practices & 0.34 & 0.000 \\
Opportunity-Enhancing HRM Practices & 0.47 & 0.013 \\
\hline
\end{tabular}

Notes: Dependent variable: Sustainable Competitive Advantage

The results indicate that all research's hypotheses were accepted, where the most significant impact is for the ability-enhancing human resource management practices $(\beta=0.51$, P-value $<0.05)$, followed by opportunity-enhancing human resource management practices $(\beta=0.47, \mathrm{P}$-value $<0.05)$ and motivation-enhancing human resource management practices $(\beta=0.34, \mathrm{P}$ value $<0.05$ ) on sustainable competitive advantage.

\section{Conclusion and discussion}

This research aimed to explore the impact of AMO model enhancing human resource management practices on sustainable competitive advantage. The results have indicated that there was an impact of AMO model enhancing human resource management practices on the sustainable competitive advantage which is consistent with the findings of Albrecht et al. (2015) and Bułat (2019). 


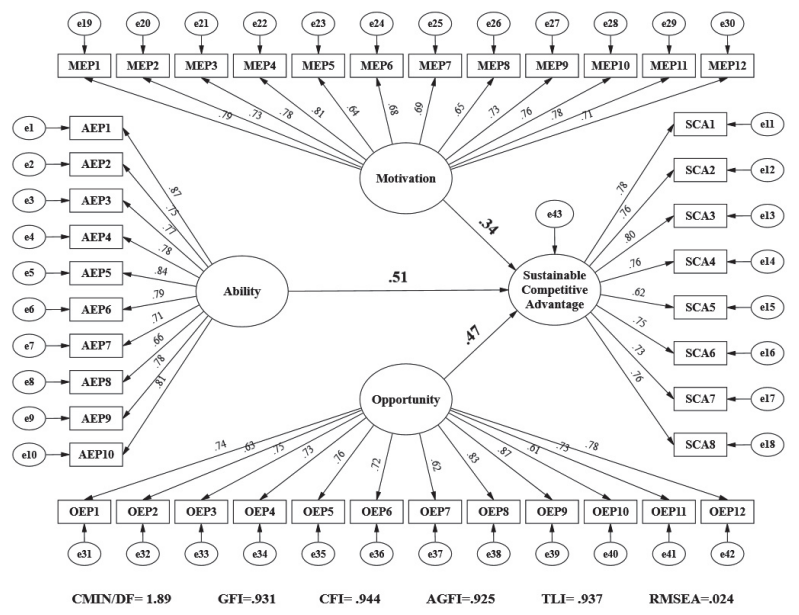

Fig. 2. Structural Model

Based on this result, the organizations need to adopt strategies to focus on the abilities of human resource management practices by recruiting the talent candidates. They need to select the best of them for employment in their teams. Also, improving their employees' capabilities and skills by activating the training programs may lead the organization in providing novel products and services. Moreover, it helps to improve an organization's products and service quality to the superiority of their rivals. Furthermore, there is a need on empowering their employees by sharing them in decision making and building communication bridges between different managerial levels within an organization to enhance their abilities to achieve their goals through effective methods to cope with environmental challenges more rapidly. Besides, organizations could focus on encouraging the employees by providing them with appropriate compensation related to their performance result and create a safe job environment that increases their affiliation and loyalty to accomplish an organization's goals, as well as seeking to be sustainable of an organization's business.

\section{Recommendations}

This research examined the impact of AMO enhancing human resource management practices on sustainable competitive advantage. Based on the results, the research presented many recommendations to encourage the managers and decisionmakers to increase required efforts toward the ability on enhancing human resource management practices by adopting appropriate recruitment strategies. That enables to attract talent from job markets, which ensures providing innovative products and services to their customers and attains sustainable competitive advantage. Besides, emphasize must be on motivation activities to build a good relationship with their employees through monetary and non-monetary compensations for highperformance employees and encourage the teamwork to build a shared culture oriented to accomplish the organization's goals.

\section{Limitation and direction for future researches}

This research has provided a contribution related to the relationship between AMO model enhancing human resource management and sustainable competitive advantage; however, it had some limitations. The first was related to the research variables, where the current research examined the impact of AMO model on sustainable competitive advantage, the future studies could link a relationship between the AMO model and other variables such as competitive capability, organizational success, and job performance. The second limitation is related to research population referred to insurance companies, where the future studies could conduct with other economies sectors as the health sector or industrial sector. The final limitation is related to the research sample, which consisted of 103 managers in the top managerial levels and the future studies could increase the sample by conducting with multi sectors which enables us to generalize the results better.

\section{References}

Ab Hamid, M. R., Sami, W., \& Sidek, M. M. (2017, September). Discriminant validity assessment: Use of Fornell \& Larcker criterion versus HTMT criterion. In Journal of Physics: Conference Series (Vol. 890, No. 1, p. 012163). IOP Publishing.

Al-Abdallah, G. M., Abdallah, A. B., \& Hamdan, K. B. (2014). The impact of supplier relationship management on competitive performance of manufacturing firms. International Journal of Business and Management, 9(2), 192-202.

Albrecht, S. L., Bakker, A. B., Gruman, J. A., Macey, W. H., \& Saks, A. M. (2015). Employee engagement, human resource management practices and competitive advantage: An integrated approach. Journal of Organizational Effectiveness: People and Performance, 2(1), 7-35. 
Al-Hawary, S.I.S., \& Al-Namlan, A.A. (2018). Impact of electronic human resources management on the organizational learning at the private hospitals in the state of Qatar. Global Journal of Management and Business Research: A Administration and Management, 18(7), 1-11.

Al-Hawary, S.I.S., \& Mohammed, A.K. (2017). Impact of team work traits on organizational citizenship behavior from the viewpoint of the employees in the education directorates in North region of Jordan. Global Journal of Management and Business, 17(2-A), 23-40.

Al-Hawary, S.I.S., Abdul Aziz Allahow, T.J., \& Aldaihani, F.M.F. (2018). Information technology and administrative innovation of the central agency for information technology in Kuwait. Global Journal of Management and Business, 18(11A), 1-16.

Almutawa, Z., Muenjohn, N., \& Zhang, J. (2016). The effect of human resource management system on employees' commitment: The mediating role of the AMO model. The Journal of Developing Areas, 50(6), 17-29.

Appelbaum, E. (ed.) (2000) Manufacturing Advantage: Why High-Performance Work Systems Pay Off.

Bainbridge, H. (2015) Devolving people management to the line: How different rationales for devolution influence people management effectiveness. Personnel Review, 44(6), 847-865.

Barney, J. B. (2000). Firm resources and sustained competitive advantage. In Economics Meets Sociology in Strategic Management (pp. 203-227). Emerald Group Publishing Limited.

Bos-Nehles, A.C., Van Riemsdijk, M.J., \& KeesLooise, J. (2013). Employee perceptions of line management performance: applying the AMO theory to explain the effectiveness of line managers' HRM implementation: Employee perceptions of line management performance. Human Resource Management, 52(6), 861-877.

Bowman, C., \& Ambrosini, V. (2003). How the resource-based and the dynamic capability views of the firm inform corporatelevel strategy. British Journal of Management, 14(4), 289-303.

Bułat, E. (2019). Human Resource Management practices that translate into sustainable competitive advantage. The Central European Review of Economics and Management, 3(1), 115.

Čirjevskis, A. (2019). The role of dynamic capabilities as drivers of business model innovation in mergers and acquisitions of technology-advanced Firms. Journal of Open Innovation and Technology Marketing Complex, 5(1), 1-16.

Ehrnrooth, M., \& Björkman, I. (2012). An integrative HRM process theorization: Beyond signalling effects and mutual gains: An integrative HRM process theorization. Journal of Management Studies, 49(6), 1109-1135.

Enders, C.K., \& Mansolf, M. (2018). Assessing the fit of structural equation models with multiply imputed data. Psychological Methods, 23(1), 76-93.

Gouillart, J.F. (2014). The race to implement co-creation of value with stakeholders: five approaches to competitive advantage. Randall and Brian Leavy R (ed.) Strategy \& Leadership, 42(1), 2-8.

Hair, J.F. (ed.) (2010) Multivariate Data Analysis. $7^{\text {th }}$ ed. Upper Saddle River, NJ: Prentice Hall.

Hancock, G.R., Stapleton, L.M., \& Mueller, R.O. (eds) (2019). The Reviewer's Guide to Quantitative Methods in the Social Sciences. Second Edition. New York: Routledge, Taylor \& Francis Group.

Harney, B., \& Jordan, C. (2008) Unlocking the black box: line managers and HRM-Performance in a call centre context. International Journal of Productivity and Performance Management, 57(4), 275-296.

Holdford, D.A. (2018) Resource-based theory of competitive advantage - a framework for pharmacy practice innovation research. Pharmacy Practice, 16(3), 1351. DOI: 10.18549/PharmPract.2018.03.1351.

Howard, J. L., Gagné, M., Morin, A. J., \& Forest, J. (2018). Using bifactor exploratory structural equation modeling to test for a continuum structure of motivation. Journal of Management, 44(7), 2638-2664.

Jabir, A. S. (2019). Quality of Service and its Impact in Achieving Competitive Advantage. Journal of University of Babylon for Pure and Applied Sciences, 27(2), 208-227.

Jiang, K., Lepak, D. P., Han, K., Hong, Y., Kim, A., \& Winkler, A. L. (2012). Clarifying the construct of human resource systems: Relating human resource management to employee performance. Human Resource Management Review, 22(2), 73-85.

Jiang, W. (2018). A correlation coefficient for belief functions. International Journal of Approximate Reasoning, 103, 94106.

Khan, S.Z., Yang, Q., \& Waheed, A. (2019). Investment in intangible resources and capabilities spurs sustainable competitive advantage and firm performance. Corporate Social Responsibility and Environmental Management, 26(2), $285-295$.

Klar, S., \& Leeper, T.J. (2019). Identities and intersectionality: A case for purposive sampling in SURVEY-EXPERIMENTAL Research. In: Lavrakas P, Traugott M, Kennedy C, et al. (eds) Experimental Methods in Survey Research. 1st ed. Wiley, pp. 419-433. DOI: 10.1002/9781119083771.ch21.

Kroon, B., Van De Voorde, K., \& Timmers, J. (2013). High performance work practices in small firms: a resource-poverty and strategic decision-making perspective. Small Business Economics, 41(1), 71-91.

Kundu, S.C., \& Gahlawat, N. (2018). Ability-motivation-opportunity enhancing human resource practices and firm performance: Evidence from India. Journal of Management \& Organization, 24(5), 730-747.

Li, C., Naz, S., Khan, M. A. S., Kusi, B., \& Murad, M. (2019). An empirical investigation on the relationship between a highperformance work system and employee performance: measuring a mediation model through partial least squares-structural equation modeling. Psychology Research and Behavior Management, 12, 397.

Ma, Z., Long, L., Zhang, Y., Zhang, J., \& Lam, C. K. (2017). Why do high-performance human resource practices matter for team creativity? The mediating role of collective efficacy and knowledge sharing. Asia Pacific Journal of Management, 34(3), 565-586. 
Mahdi, O.R., Nassar, I.A., \& Almsafir, M.K. (2019b). Knowledge management processes and sustainable competitive advantage: An empirical examination in private universities. Journal of Business Research 94: 320-334.

Pervan, M., Curak, M., \& Pavic Kramaric, T. (2018). The influence of industry characteristics and dynamic capabilities on firms' profitability. International Journal of Financial Studies, 6(1), 4.

Marin-Garcia, J. A., \& Tomas, J. M. (2016). Deconstructing AMO framework: A systematic review. Intangible Capital, 12(4), 1040-1087.

Marsh, H. W., Guo, J., Dicke, T., Parker, P. D., \& Craven, R. G. (2019). Confirmatory Factor Analysis (CFA), Exploratory Structural Equation Modeling (ESEM), and Set-ESEM: Optimal Balance Between Goodness of Fit and Parsimony. Multivariate Behavioral Research, 1-18. DOI: 10.1080/00273171.2019.1602503.

Maury, B. (2018). Sustainable competitive advantage and profitability persistence: Sources versus outcomes for assessing advantage. Journal of Business Research, 84, 100-113.

Meneses, L., Torres, S., Miller, K. M., \& Barbosa, M. R. (2019). Extending the use of the Body Appreciation Scale-2 in older adults: A Portuguese validation study. Body image, 29, 74-81.

Morton, J., Stacey, P., \& Mohn, M. (2018). Building and maintaining strategic agility: an agenda and framework for executive IT leaders. California Management Review, 61(1), 94-113.

Nadarajah, D., \& Latifah Syed Abdul Kadir, S. (2014). A review of the importance of business process management in achieving sustainable competitive advantage. The TQM journal, 26(5), 522-531.

Obeidat, S. M., Mitchell, R., \& Bray, M. (2016). The link between high performance work practices and organizational performance: Empirically validating the conceptualization of HPWP according to the AMO model. Employee Relations, 38(4), 578-595.

Pak, K., Kooij, D. T., De Lange, A. H., \& Van Veldhoven, M. J. (2019). Human Resource Management and the ability, motivation and opportunity to continue working: A review of quantitative studies. Human Resource Management Review, 29(3), 336-352.

Perry, J. L., Nicholls, A. R., Clough, P. J., \& Crust, L. (2015). Assessing model fit: Caveats and recommendations for confirmatory factor analysis and exploratory structural equation modeling. Measurement in Physical Education and Exercise Science, 19(1), 12-21.

Porter, M.E. (1980). Competitive Strategy: Techniques for Analyzing Industries and Competitors. 1st.ed. New York: Free Press.

Quaye, D., \& Mensah, I. (2019) Marketing innovation and sustainable competitive advantage of manufacturing SMEs in Ghana. Management Decision, 57(7), 1535-1553.

Rahman, I. A., Rahmat, N. I., \& Nagapan, S. (2016). Structural relationship of success factors for Small Medium Enterprises (SME) contractors in PLS-SEM model. In Engineering Challenges for Sustainable Future (Vol. 173, No. 175, pp. 173175). ROUTLEDGE in association with GSE Research.

Rajiani, I., Musa, H., \& Hardjono, B. (2016). Ability, Motivation and Opportunity as Determinants of Green Human Resources Management Innovation. Research Journal of Business Management 10(1): 51-57.

Saldivia, S., Aslan, J., Cova, F., Vicente, B., Inostroza, C., \& Rincón, P. (2019). Propiedades psicométricas del PHQ-9 (Patient Health Questionnaire) en centros de atención primaria de Chile. Revista médica de Chile, 147(1), 53-60.

Santana-Sarmiento, F., Álamo-Vera, F. R., \& Saá-Pérez, D. (2019). A resource-based view of competitiveness in the wind energy sector: The case of Gran Canaria and Tenerife. Applied Sciences, 9(6), 1263.

Takahashi, A. R. W., \& Sander, J. A. (2017). Combining institutional theory with resource based theory to understand processes of organizational knowing and dynamic capabilities. European Journal of Management Issues, 25(1), 43-48.

Vermeeren, B., Kuipers, B., \& Steijn, B. (2014). Does leadership style make a difference? Linking HRM, job satisfaction, and organizational performance. Review of Public Personnel Administration, 34(2), 174-195.

Wang, C. J. (2019). Linking sustainable human resource management in hospitality: An empirical investigation of the integrated mediated moderation model. Sustainability, 11(4), 1066.

Wang, G. J., Xie, C., \& Stanley, H. E. (2018). Correlation structure and evolution of world stock markets: Evidence from Pearson and partial correlation-based networks. Computational Economics, 51(3), 607-635.

Williams, B., Onsman, A., \& Brown, T. (2010). Exploratory factor analysis: A five-step guide for novices. Australasian Journal of Paramedicine, 8(3).

Xin, J., Song, C., Fuji, X., \& Zexia, L. (2018). Multi-dimensional Influence of Dynamic Capabilities on Innovation Performance in Knowledge-intensive Service Enterprises. Science Journal of Business and Management, 6(4), 81.

Zhang, B., \& Morris, J.L. (2014). High-performance work systems and organizational performance: testing the mediation role of employee outcomes using evidence from PR China. The International Journal of Human Resource Management, 25(1), $68-90$.

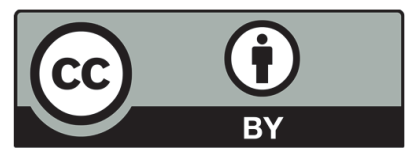

(C) 2020 by the authors; licensee Growing Science, Canada. This is an open access article distributed under the terms and conditions of the Creative Commons Attribution (CC-BY) license (http://creativecommons.org/licenses/by/4.0/). 